\title{
Pengembangan Media Interaktif Berbasis Google Slide Berbantu Aplikasi Pear Deck pada Materi Sistem Pertahanan Tubuh
}

\author{
Lia Fakhriah*, R. Ading Pramadi, Milla Listiawati \\ Program Studi Pendidikan Biologi, Universitas Islam Negeri Sunan Gunung Djati, Bandung, Indonesia
}

*Coresponding Author: liafakhriahbio@gmail.com

Article History:

Received 2021-09-02

Revised 2022-01-02

Accepted 2022-01-22

DOI:

10.31949/educatio.v8i1.1473

\begin{abstract}
This research is motivated by the challenges of 21st century learning which focuses on the use of technology. In addition, the covid-19 pandemic has not ended until now requires teachers and students to use the media appropriate in online learning. Google Slides media with Pear Deck app is one of the media that can be used in learning online. This media is easily accessible via Chrome or other Browsers. The purpose of this research is to describe the stages of media development and students' responses to the media and analyze the feasibility of the media. Method the research used is Research and Development with a 3D model (Define, Design and Develop). The research instrument used is the sheet observations, interview sheets teacher and student needs questionnaires, validation questionnaires media experts, material experts and biology teachers, readability questionnaires and student responses. Results the research obtained the percentage value of media experts by $88 \%$ (very feasible), material experts by $84 \%$ (adequate), biology teacher by $77 \%$ (decent), readability test students by $81 \%$ (adequate) and student responses of $78 \%$ (adequate). Could concluded that this media is feasible to be used in learning at school.
\end{abstract}

Keywords: interactive media; google slides; pear deck; immune system

\begin{abstract}
Abstrak
Penelitian ini dilatarbelakangi oleh tantangan pembelajaran abad 21 yang menitikberatkan pada penggunaan teknologi. Selain itu, pandemi covid-19 yang belum berakhir hingga saat ini menuntut guru dan siswa untuk menggunakan media yang tepat dalam pembelajaran daring. Media Google Slide berbantu aplikasi Pear Deck merupakan salah satu media yang dapat digunakan dalam pembelajaran daring. Media ini mudah diakses melalui Chrome atau Browser lainnya. Tujuan dari penelitian ini adalah untuk mendeskripsikan tahapan pengembangan media dan respon siswa terhadap media serta menganalisis kelayakan media. Metode penelitian yang digunakan adalah Research and Development dengan model 3D (Define, Design dan Develop). Instrumen penelitian yang digunakan yaitu lembar observasi, lembar wawancara, angket kebutuhan guru dan siswa, angket validasi ahli media, ahli materi dan guru biologi, angket keterbacaan dan respon siswa. Hasil penelitian diperoleh persentase nilai dari ahli media sebesar 88\% (sangat layak), ahli materi sebesar 84\% (layak), guru biologi sebesar $77 \%$ (layak), uji keterbacaan siswa sebesar $81 \%$ (layak) dan respon siswa sebesar 78\% (layak). Dapat disimpulkan bahwa media ini layak untuk digunakan dalam pembelajaran di sekolah.
\end{abstract}

Kata Kunci: media interaktif; google slide; pear deck; sistem pertahanan tubuh

\section{PENDAHULUAN}

Pembelajaran abad 21 memberikan tantangan yang berat kepada guru dan siswa. Salah satu tantangannya yaitu guru dituntut untuk menguasai ilmu pengetahuan dan teknologi secara mumpuni. Teknologi dapat digunakan oleh guru dalam membuat media pembelajaran yang dapat menambah minat siswa serta mempermudah siswa dalam memahami materi. Dikembangkannya teknologi pembelajaran bertujuan untuk memfasilitasi siswa agar dapat memahami materi secara mendalam serta untuk mencetak siswa yang menguasai bidang keilmuan. Pembelajaran harus cepat menerima perubahan ke arah yang lebih 
baik mengikuti perkembangan teknologi, salah satu contohnya adalah pembelajaran biologi (Sayekti dkk, 2017). Pembelajaran biologi diharapkan mampu mempersiapkan siswa agar dapat menggunakan konsepkonsep sains yang telah mereka pelajari untuk memecahkan masalah yang dihadapi dalam kehidupan seharihari, memiliki sikap ilmiah, serta menggunakan konsep-konsep ilmiah untuk mengambil keputusan yang tepat sehingga mereka dapat berpikir dan bertindak secara ilmiah (Suryaningsih, 2017).

Pada masa pandemi covid-19 pemerintah berupaya memaksimalkan pelayanan pendidikan. Salah satunya yaitu dengan menerapkan kebijakan berupa kurikulum darurat covid-19. Kebijakan Pembelajaran Jarak Jauh (PJJ) menghadirkan tantangan baru bagi guru untuk menggunakan internet sebagai alternatif pencegahan penyebaran covid-19. Guru-guru diharuskan menyusun Rencana Pelaksanaan Pembelajaran (RPP) mengikuti aturan kurikulum darurat covid-19 agar kegiatan pembelajaran dapat berjalan dengan baik meskipun dilakukan secara online. Rumah dapat dijadikan ruang belajar dan siswa harus sadar serta merasa bahwa mereka sedang mengikuti kegiatan pembelajaran. Kegiatan pembelajaran dilakukan dengan menggunakan berbagai macam aplikasi yang mudah diakses oleh siswa seperti WhatsApp Group, Google Doc, Google Classroom, Google Form, Zoom Meeting dan Ruangguru (Jusuf dan Maaku, 2020).

Mekanisme yang rumit dan sulit dipahami merupakan salah satu kendala bagi siswa dalam mempelajari materi sistem pertahanan tubuh. Hal ini berdampak pada rendahnya hasil belajar siswa sehingga perlu dilakukan upaya untuk meningkatkannya (Nisa et al, 2018; Tarigan et al, 2020; Widyastuti et al, 2014). Di samping itu, penggunaan buku teks dianggap kurang maksimal dalam memfasilitasi siswa untuk meningkatkan motivasi, minat dan pemahaman konten sistem pertahanan tubuh (Trisnaningsih, 2016). Berdasarkan hasil wawancara dengan guru biologi di salah satu Madrasah Aliyah Negeri di Bekasi diketahui bahwa kesulitan yang dialami siswa diantaranya adalah muatan materi sistem pertahanan tubuh pada buku paket kurikulum 2013 terlalu banyak sehingga menimbulkan rasa bosan, kurangnya motivasi belajar dikarenakan harus belajar mandiri karena masih dalam keadaan pandemi, serta banyak istilah-istilah yang sulit dipahami oleh siswa. Media Pembelajaran Jarak Jauh (PJJ) yang digunakan oleh guru yaitu media Zoom, WhatsApp Group, Google Classroom, E-Learning dan Youtube.

Pembelajaran merupakan kegiatan belajar (learning) dan mengajar (teaching) yang diakumulasikan (Dewi, 2018). Kegiatan pembelajaran adalah sistem yang tersusun atas beberapa komponen diantaranya guru, siswa, tujuan, prosedur, fasilitas, materi dan media (Rusman, 2017). Media pembelajaran merupakan sesuatu yang berupa software atau hardware yang digunakan untuk menyampaikan materi pembelajaran dari berbagai sumber belajar kepada siswa (Adam, 2015; Dewi et al, 2018; Jauhari, 2018). Media mampu merangsang minat, perasaan, pikiran dan perhatian siswa sehingga kegiatan pembelajaran dapat berjalan lebih efektif (Jalinus dan Ambiyar, 2016).

Google Slide adalah tool presentasi yang dibuat secara online. Google Slide dapat diakses melalui komputer manapun dengan jaringan internet karena tool ini berbasis Cloud. Google Slide dapat diakses menggunakan akun google yang dimiliki. Selain itu, file yang dibuat dapat diedit dan dikolaborasi secara real time (Indriasari, 2020). Terdapat beberapa kelebihan Google Slide diantaranya kemudahan penggunaan (Google Slide tidak sulit untuk dipelajari), berbasis web (memudahkan untuk menautkan dokumen di halaman web), kolaborasi (dapat dibuat dan diedit secara bersama-sama), dan inovatif (memiliki sejumlah fitur inovatif seperti fitur $Q \& A / \operatorname{tanya}$ jawab yang dapat membuat presentasi menjadi lebih hidup). Selain itu, Google Slide memiliki kekurangan seperti untuk mengaksesnya membutuhkan koneksi internet, jika terjadi kesalahan yang dilakukan oleh salah satu pengguna Google Slide maka slide yang muncul di pengguna lainnya akan salah, serta lebih sedikit pilihan efek dan tema (Indriasari, 2020).

Pear Deck adalah platform yang terintegrasi dengan Google dan Microsoft Documents untuk menambahkan aktivitas interaktif atau tools pembelajaran online lainnya. Contoh penggunaannya yaitu guru dapat membuat media interaktif untuk siswa yang dapat digunakan oleh siswa selama belajar mandiri di rumah. Pear Deck dapat meningkatkan interaksi selama pembelajaran online serta guru dapat memberikan penilaian terhadap siswa selama pembelajaran berlangsung (Lacey, \& Smith, 2021). Menurut Khatim dan Ahhabi (2020) langkahlangkah belajar menggunakan Google Slide add-on Pear Deck yaitu: (1) buatlah file presentasi atau upload file presentasi yang telah dibuat ke Google Slide, (2) bagikan screen presentasi kepada siswa dengan cara share "join 
code" atau link untuk mengakses screen presentasi, (3) mulailah presentasi interaktif dengan siswa dan (4) jika telah selesai dapat diakhiri dengan mengklik tombol "END" pada screen presentasi.

Dari latar belakang tersebut, maka penelitian ini bertujuan untuk mendeskripsikan tahapan pengembangan media interaktif berbasis Google Slide berbantu aplikasi Pear Deck pada materi sistem pertahanan tubuh, menganalisis kelayakan media interaktif berbasis Google Slide berbantu aplikasi Pear Deck pada materi sistem pertahanan tubuh dan mendeskripsikan respon siswa terhadap media interaktif berbasis Google Slide berbantu aplikasi Pear Deck pada materi sistem pertahanan tubuh.

\section{METODE PENELITIAN}

Pendekatan yang digunakan dalam penelitian ini adalah pendekatan deskriptif dengan metode penelitian Research and Development. Penelitian ini dilaksanakan dari bulan Maret s/d Agustus 2021 di Madrasah Aliyah Negeri 3 Bekasi yang beralamat di Desa Lenggahjaya, Kecamatan Cabangbungin, Kabupaten Bekasi, Provinsi Jawa Barat. Sampel yang digunakan sebanyak 15 orang siswa kelas XII IPA. Sampel ini diperoleh dengan melakukan teknik purposive sampling.

Penelitian pengembangan media ini merujuk pada model 4D yang dikemukakan oleh Thiagarajan kemudian dimodifikasi menjadi model 3D. Berikut adalah penjabaran tahapan model 3D yang dilakukan: (1) tahap define/pendefinisian adalah tahap untuk mendefinisikan serta menetapkan syarat-syarat dalam pembelajaran dengan lima langkah berikut: (a) analisis ujung depan, (b) analisis siswa, (c) analisis tugas, (d) analisis konsep dan (e) perumusan tujuan pembelajaran; (2) tahap design/perancangan merupakan tahap untuk mempersiapkan prototype media interaktif dengan empat langkah berikut: (a) penetapan kriteria acuan, (b) pemilihan media, (c) pemilihan format dan (d) rancangan awal; (3) tahap develop/pengembangan adalah tahap yang dilakukan untuk menghasilkan produk media interaktif yang telah direvisi oleh para ahli dengan meliputi dua langkah berikut: (a) validasi-revisi dan (b) uji coba terbatas.

Penelitian media interaktif ini memiliki dua jenis data yaitu data kualitatif dan data kuantitatif. Data dikumpulkan melalui wawancara dengan guru mencakup semua informasi yang dibutuhkan dalam mengembangkan media ini, penyebaran angket, dokumentasi berisi foto-foto yang berkaitan dengan penelitian serta instrumen penelitian. Instrumen penelitian yang digunakan yaitu lembar observasi, lembar wawancara, angket kebutuhan guru dan siswa, angket validasi ahli media, ahli materi dan guru biologi, angket keterbacaan dan respon siswa.

Teknik analisis data yang digunakan dalam penelitian pengembangan media interaktif ini adalah analisis hasil uji kelayakan dan analisis respon siswa. Analisis hasil uji kelayakan terdiri atas analisis hasil uji kelayakan media, analisis hasil uji kelayakan materi serta analisis hasil uji keterbacaan siswa. Data yang telah diperoleh selanjutnya diolah dengan menggunakan rumus persentase deskriptif. Hasil skor persentase diinterpretasikan dengan kriteria kualifikasi berdasarkan tabel 1.

Tabel 1. Kriteria Hasil Uji Kelayakan \& Respon Siswa

\begin{tabular}{lc}
\hline Kriteria & Persentase \\
\hline Tidak layak & $<55 \%$ \\
Kurang layak & $55 \%-74 \%$ \\
Layak & $75 \%-84 \%$ \\
Sangat layak & $85 \%-100 \%$ \\
\hline
\end{tabular}

\section{HASIL DAN PEMBAHASAN}

Analisis uji kelayakan media dilakukan berdasarkan hasil validasi ahli media. Kelayakan media dilihat dari berbagai aspek yaitu aspek teknik penyajian, aspek media secara khusus dan aspek visual. Hasil persentase aspek-aspek tersebut dapat dilihat pada tabel 2. Analisis uji kelayakan materi dilakukan berdasarkan hasil validasi ahli materi. Persentase kelayakan materi sebesar $84 \%$ dengan kriteria layak. 
Tabel 2. Persentase Aspek Validasi Media

\begin{tabular}{ccc}
\hline $\begin{array}{c}\text { Aspek Validasi } \\
\text { Media }\end{array}$ & Persentase & Kriteria \\
\hline Teknik Penyajian & $87 \%$ & Sangat Layak \\
Media & $93 \%$ & Sangat Layak \\
Visual & $80 \%$ & Layak \\
Rata-Rata & $87 \%$ & Sangat Layak \\
\hline
\end{tabular}

Kelayakan materi dilihat dari dua aspek yaitu aspek isi materi dan aspek kebahasaan. Hasil persentase aspek-aspek tersebut dapat dilihat pada tabel 3.

Tabel 3. Persentase Aspek Validasi Materi

\begin{tabular}{ccc}
\hline Aspek Validasi Materi & Persentase & Kriteria \\
\hline Isi Materi & $84 \%$ & Layak \\
Kebahasaan & $85 \%$ & Sangat Layak \\
Rata-Rata & $84 \%$ & Layak \\
\hline
\end{tabular}

Uji keterbacaan siswa dilakukan dengan cara memberi angket kepada 15 orang siswa yang berpartisipasi dalam uji coba terbatas. Terdapat beberapa aspek yang dimuat pada angket uji keterbacaan siswa diantaranya kejelasan dan kemudahan dalam memahami penjelasan materi, kuis dan soal evaluasi. Hasil analisis uji keterbacaan siswa dapat dilihat pada tabel 4.

Tabel 4. Persentase Aspek Uji Keterbacaan Siswa

\begin{tabular}{ccc}
\hline Aspek Keterbacaan Siswa & Persentase & Kriteria \\
\hline Penjelasan Materi & $84,4 \%$ & Layak \\
Kuis & $80,5 \%$ & Layak \\
Soal Evaluasi & $77,7 \%$ & Layak \\
Rata-Rata & $81 \%$ & Layak \\
\hline
\end{tabular}

Respon siswa dijaring melalui angket yang diberikan kepada 15 orang siswa yang telah melakukan uji coba terbatas dan uji keterbacaan. Aspek yang terdapat pada angket respon siswa diantaranya aspek materi, media, kuis dan soal evaluasi. Hasil analisis respon siswa yaitu:

Tabel 5. Persentase Aspek Respon Siswa

\begin{tabular}{ccc}
\hline Aspek Respon Siswa & Persentase & Kriteria \\
\hline Materi & $78 \%$ & Layak \\
Media & $76 \%$ & Layak \\
Kuis & $81 \%$ & Layak \\
Soal Evaluasi & $77 \%$ & Layak \\
Rata-Rata & $84 \%$ & Layak \\
\hline
\end{tabular}

Penelitian dan pengembangan ini bertujuan untuk menghasilkan produk berupa media interaktif berbasis Google Slide berbantu aplikasi Pear Deck pada materi sistem pertahanan tubuh. Hal ini sesuai dengan pernyataan yang diungkapkan oleh Saputro (2017) bahwa metode penelitian dan pengembangan adalah metode penelitian yang menghasilkan produk. Untuk menghasilkan produk ini, maka dilakukan tahapantahapan penelitian dan pengembangan yaitu tahap define, design dan develop. Ketiga tahapan tersebut merupakan penyederhanaan dari model 4D Thiagarajan. Model 4D Thiagarajan hanya dijadikan panduan saja, untuk pelaksanaannya dapat disesuaikan dengan keadaan di lapangan. Hal ini selaras dengan Subakti dkk (2021) yang menyatakan bahwa model-model dari penelitian pengembangan boleh dijadikan panduan, untuk pelaksanaannya dapat disesuaikan dengan kondisi di lapangan. 
Pada tahap define dilakukan studi pendahuluan yang bertujuan untuk mengambil data awal yang akan dijadikan acuan pada tahap design. Menurut Saputro (2017) studi pendahuluan dilakukan dengan menganalisis kebutuhan dapat melalui wawancara, angket dan dokumentasi. Pada tahap design dilakukan perancangan media yang akan dikembangkan. Hal ini selaras dengan pernyataan Hidayat dkk (2020) yaitu tahap design merupakan kegiatan membuat rancangan produk media yang akan dikembangkan. Tahap develop adalah tahap akhir dari pengembangan media interaktif yang menghasilkan produk media pembelajaran. Hal ini selaras dengan Simarmata dkk (2017) yang menyatakan bahwa tahap develop merupakan tahap yang menghasilkan produk akhir berupa media pembelajaran, metode, model atau lainnya.

Uji coba terbatas dilakukan kepada 15 orang siswa kelas XII IPA. Terdapat beberapa siswa yang merupakan responden angket kebutuhan siswa terhadap media yang dikembangkan pada tahap studi pendahuluan (saat masih di kelas XI). Jumlah ini sudah memenuhi syarat untuk dilakukannya uji coba terbatas. Hal ini selaras dengan pernyataan Saputro (2017) yaitu jumlah minimum untuk dilakukan uji coba terbatas sebanyak 12 orang siswa. Langkah-langkah uji coba terbatas penggunaan media interaktif berbasis Google Slide berbantu aplikasi Pear Deck pada materi sistem pertahanan tubuh yaitu: (1) guru meyampaikan pendahuluan dan memberikan link media presentasi yang telah valid kepada siswa melalui Whats App Group, (2) guru melakukan pengecekan kehadiran siswa dengan melihat keterangan pada setiap slide mengenai jumlah siswa yang menyimak slide, (3) guru menyampaikan tujuan pembelajaran dan memotivasi untuk belajar, (4) siswa menyimak materi yang ditampilkan dalam slide, (4) siswa dapat bertanya, menjawab pertanyaan, serta menanggapi secara langsung pada slide yang telah disiapkan oleh guru, (5) guru memberi feedback terhadap tanggapan siswa secara langsung, (6) guru mempersilahkan salah satu siswa untuk memberikan kesimpulan dan (7) guru menutup kegiatan pembelajaran. Respon siswa pada slide interaktif dapat dilihat pada gambar 1.

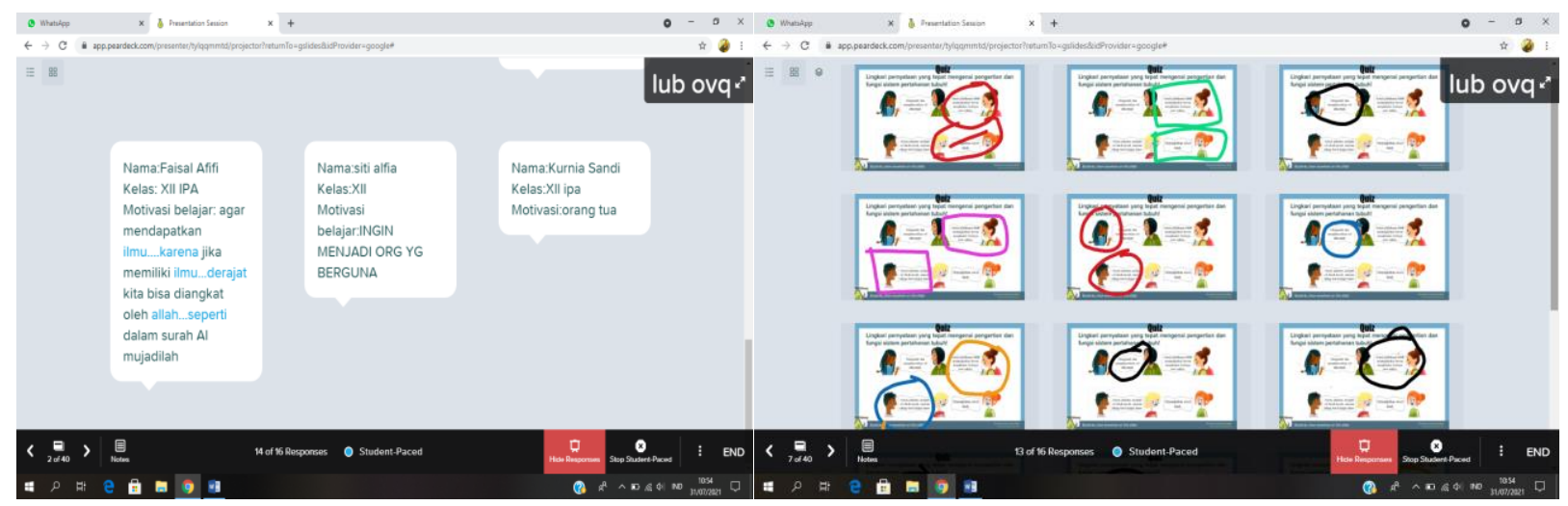

Gambar 1. Respon Siswa pada Slide Interaktif

Berdasarkan keseluruhan hasil penelitian diketahui bahwa media yang dikembangkan layak untuk digunakan dalam pembelajaran. Hal tersebut dapat dilihat dari hasil analisis uji kelayakan dari segi media yaitu sebesar 88\%, dari segi materi sebesar 84\% serta penilaian guru biologi terhadap media sebesar 77\% . Dari penilaian ahli media, ahli materi dan guru biologi didapat rata-rata sebesar 83\% dengan kriteria layak. Hal ini selaras dengan Hariadi (2019) yang menyatakan bahwa persentase kelayakan dengan rentang 75\%-84\% diinterpretasikan dengan kriteria layak. Tidak semua media yang dibuat oleh guru atau yang terdapat di sekolah layak untuk digunakan dalam pembelajaran. Media yang dapat digunakan seharusnya media yang benar-benar telah divalidasi dan direvisi dengan sebaik-baiknya agar tidak terjadi miskonsepsi terhadap materi yang dimuat pada media (Susilana \& Riyana, 2009). Ciri media pembelajaran yang layak digunakan yaitu media tersebut mempunyai kemampuan untuk merekam, melestarikan, menyimpan serta merekontruksi suatu objek/kejadian tertentu (bersifat fiksatif), dan proses atau peristiwa yang membutuhkan jangka waktu yang panjang dapat disajikan dalam waktu dua atau tiga menit dengan teknik time lapse recording (bersifat manipulatif) (Ismail et al, 2020). 
Setelah dilakukan uji coba terbatas maka dilakukan uji keterbacaan dengan menyebar angket tertutup kepada 15 orang siswa. Berdasarkan hasil analisis uji keterbacaan siswa diketahui bahwa hasil uji keterbacaan siswa sebesar $81 \%$ dengan kriteria layak. Dalam pengembangan media pembelajaran, uji keterbacaan penting dilakukan, komentar dan saran siswa dijadikan acuan untuk merevisi media, agar media yang dikembangkan benar-benar memenuhi kebutuhan pengguna (dalam hal ini adalah siswa) (Winarni \& Kusumaningtyas, 2018).

Setelah dilakukan uji coba terbatas dan uji keterbacaan siswa maka perlu diperhatikan bagaimana respon siswa terhadap media yang dikembangkan. Hal ini sesuai dengan Susilana dan Riyana (2009) menyatakan bahwa perlu diamati respon siswa terhadap media yang dikembangkan karena sasaran akhir dari pengembangan media adalah mengetahui hasil respon siswa terhadap media tersebut.

Untuk menjaring respon siswa terhadap media digunakan angket tertutup yang berisi 16 pernyataan. Jumlah responden sebanyak 15 orang siswa yang merupakan kelas XII IPA. Skala pengukuran respon siswa yang digunakan adalah skala Likert. Berdasarkan hasil analisis angket respon siswa diketahui persentase ratarata sebesar 78\% dengan kriteria layak. Menurut Hariadi (2019) rentang persentase kelayakan dengan kriteria layak yaitu sebesar $75 \%-84 \%$. Ketentuan dari rentang tersebut yaitu media layak untuk diimplementasikan dalam pembelajaran serta dilakukan sedikit revisi sesuai catatan ahli.

Berdasarkan hasil analisis angket respon siswa, terdapat 33\% siswa yang menyatakan media interaktif ini kurang layak, $40 \%$ siswa menyatakan layak dan $27 \%$ siswa menyatakan sangat layak. Selain diukur menggunakan skala Likert, pada angket respon siswa diberikan kolom komentar dan saran. Mayoritas saran yang diberikan oleh siswa yaitu penambahan animasi untuk mempermudah dalam memahami materi yang dimuat pada media. Menurut Purba dkk (2020) dengan menambahkan animasi pada media pembelajaran diharapkan dapat mengembangkan kreativitas dan intelektual siswa serta memotivasi siswa untuk belajar. Respon siswa dapat berupa respon positif dan negatif. Kedua respon tersebut dapat dilihat dari ketertarikan siswa terhadap media, ekspresi dan pendapat langsung yang dikemukakan oleh siswa (Susilana \& Riyana, 2009). Kelayakan media untuk digunakan dalam pembelajaran didukung oleh respon positif siswa diantaranya siswa dapat memahami penjelasan materi, sangat bagus dan mudah dipahami, kuis mudah dipahami, penjelasan materi dan soal evaluasi mampu membuat siswa lebih semangat dalam pembelajaran serta siswa senang belajar menggunakan media ini.

\section{KESIMPULAN}

Pengembangan media interaktif ini terdiri atas tiga tahap yaitu tahap define, design dan develop. Pada tahap define dilakukan studi pendahuluan untuk mendapatkan data awal yang akan dijadikan acuan dalam melaksanakan tahap design. Pada tahap design dihasilkan rancangan awal yang akan divalidasi oleh dosen ahli dan guru biologi. Pada tahap develop, setelah media divalidasi kemudian direvisi berdasarkan masukan validator. Berdasarkan hasil analisis uji kelayakan dari segi media dan materi yang telah divalidasi oleh dosen ahli dan guru biologi, media interaktif ini dinyatakan layak dengan persentase kelayakan sebesar $83 \%$ dan hasil uji keterbacaan siswa yang menghasilkan persentase kelayakan sebesar $81 \%$ dengan kriteria layak. Berdasarkan hasil analisis angket respon siswa, persentase rata-rata respon siswa sebesar 78\% dengan kriteria layak.

\section{DAFTAR PUSTAKA}

Adam, S. (2015). Pemanfaatan media pembelajaran berbasis teknologi informasi bagi siswa kelas X SMA Ananda Batam. Computer Based Information System Journal, 3(2).

Dewi, N., Murtinugraha, R. E., \& Arthur, R. (2018). Pengembangan Media Pembelajaran Interaktif pada Mata Kuliah Teori dan Praktik Plambing di Program Studi S1 PVKB UNJ. Jurnal Pensil: Pendidikan Teknik. Sipil, 7(2), 95-104.

Dewi, E. R. (2018). Metode Pembelajaran Modern Dan Konvensional Pada Sekolah Menengah Atas. PEMBELAJAR: Jurnal Ilmu Pendidikan, Keguruan, dan Pembelajaran, 2(1), 44-52.

Hariadi, S. (2019). Best Practice Implementasi Media Pembelajaran Berbasis TIK Teks Wawancara Babasa Jawa Berbasis 
Blended Learning pada Siswa Kelas VIII. Yogyakarta: Diva Press.

Hidayat, A. S., dkk. (2020). Pengembangan Model Pembelajaran Atletik. Grobogan: CV. Sarnu Untung.

Indriasari, S. (2020). Aplikasi Office Menggunakan Google Suite. Yogyakarta: Deepublish.

Ismail, I. (2020). Teknologi Pembelajaran sebagai Media Pembelajaran. Makassar: Cendekia Publisher.

Jalinus, N., \& Ambyar. (2016). Media dan Sumber Pembelajaran. Jakarta: Kencana.

Jauhari, M. I. (2018). Peran Media Pembelajaran dalam Pendidikan Islam. Piwulang: Jurnal Pendidikan Agama Islam, 1(1), 54-67.

Khatim, M. S., \& Ahhabi, M. A. (2020). Integrating Blended Learning in Information Literacy Teaching With Pear Deck. Abu Dhabi: Zayed University.

Lacey, S., \& Smith, K. E. (2021). 50 Strategies for Your Virtual Classroom. Huntington Beach: Shell Education.

Nisa, I., Hidayat, A., \& Maspupah, M. (2015). Penerapan Strategi Pembelajaran Question Student Have (QSH) Pada Materi Sistem Pertahanan Tubuh Untuk Mengetahui Hasil Belajar Peserta Didik. Jurnal BIOEDUIN: Program Studi Pendidikan Biologi, 5(1), 1-10.

Purba, Ramen A., dkk. (2020). Pengantar Media Pembelajaran. Jakarta: Yayasan Kita Menulis.

Saputro, B. (2017). Manajemen Penelitian Pengembangan. Yogyakarta: Aswaja Pressindo.

Simarmata, J., dkk. (2017). Pengembangan Media Animasi Berbasis Hybrid Learning. Jakarta: Yayasan Kita Menulis.

Subakti, H., dkk. (2021). Inovasi Pembelajaran. Jakarta: Yayasan Kita Menulis.

Susilana, R., \& Riyana, C. (2009). Media Pembelajaran. Bandung: Wacana Prima.

Tarigan, M. R. I. M. A., Manalu, A. W., Tanjung, H. E., Saragih, J. S., \& Ula, A. (2020). Pengaruh Model Snowball Throwing Terhadap Hasil Belajar Siswa Pada Materi Sistem Pertahanan Tubuh Di Sma Swasta Medan. Jurnal Biolokus: Jurnal Penelitian Pendidikan Biologi dan Biologi, 3(2), 313-319.

Widyastuti, S., Susanti, R., \& Widianti, T. (2014). Pengembangan web educative sebagai sumber belajar pada materi sistem pertahanan tubuh. Journal of Biology Education, 3(1).

Winarni, E. W. \& Kusumaningtyas, A. (2018). Teori dan Praktik Penelitian Kuantitatif, Kualitatif, PTK, R\&D. Jakarta: Bumi Aksara. 